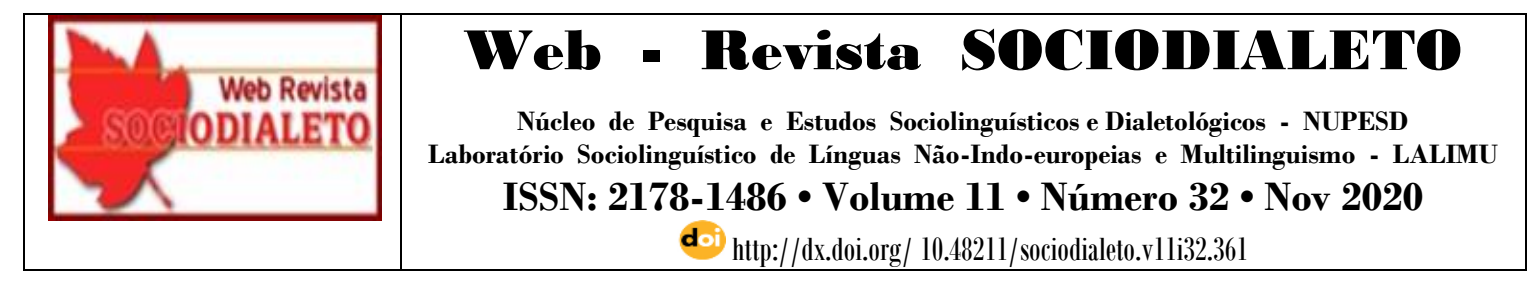

\title{
A ATUAÇÃO DA ESCOLA NA SUBSTITUIÇÃO DO VÊNETO PELO PORTUGUÊS NAS ZONAS URBANA E RURAL DE ALFREDO CHAVES, ESPÍRITO SANTO
}

\author{
Marcio Favero Fiorin (Sedu/ES) ${ }^{1}$ \\ marciofaverofiorin2@gmail.com \\ Edenize Ponzo Peres (UFES; PROFLETRAS/IFES) $)^{2}$ \\ eponzoperes@gmail.com
}

\begin{abstract}
RESUMO: Alfredo Chaves foi um dos municípios do Espírito Santo colonizados por imigrantes italianos, sobretudo da Região do Vêneto, que ali chegaram a partir de 1877, trazendo consigo a sua cultura e a sua língua. Entretanto, os crescentes contatos entre os imigrantes e seus descendentes com os falantes de português levaram a uma expressiva diminuição dos usos das variedades vênetas. Assim, este estudo busca analisar a atuação da escola no processo de substituição do vêneto pelo português em duas comunidades de Alfredo Chaves (ES): a Sede e a comunidade rural de Santa Maria de Ibitiruí. Nossos dados foram obtidos por meio entrevistas com descendentes de imigrantes italianos, além de (ex-)agentes escolares que residem nas duas localidades. As análises, feitas com base na teoria do Contato Linguístico, evidenciam que o sistema educacional atuou em favor da propagação das leis nacionalistas de Vargas e que o ensino do português ainda contribui para excluir a variação linguística nas salas de aula, culminando em situações de preconceito contra quem fala o português com influência da língua vêneta. Diante desses resultados, concluímos que se faz necessário um trabalho de apoio aos agentes escolares, por meio de formação continuada junto a eles, a fim de que a diversidade cultural e linguística seja respeitada e valorizada pela escola.
\end{abstract}

PALAVRAS-CHAVE: Contato linguístico. Imigração italiana em Alfredo Chaves, Espírito Santo. Língua vêneta. Substituição linguística. Sistema educacional.

ABSTRACT: Alfredo Chaves was one of the municipalities of the State of Espírito Santo colonized by Italian immigrants, especially those who came from Veneto and arrived in 1877, bringing their culture and their language. However, the increasing contacts between immigrants and their descendants with Portuguese speakers have led to a significant decrease in the use of Venetian varieties. Thus, this study aims to analyze the influence of schools in the process of replacing Veneto with Portuguese in two communities of Alfredo Chaves (ES): the urban area and Santa Maria de Ibitiruí, a rural community. Our data were obtained through interviews with descendants of Italian immigrants, as well as (ex-)school agents who reside in both locations. The analysis, based on the theory of Language Contact, shows that the educational system contributed to the propagation of Vargas' nationalist laws and that Portuguese teaching still contributes to exclude linguistic variation in classrooms, resulting in situations of prejudice against those who speak Portuguese with the influence of the Venetian language. In view of these results, we

\footnotetext{
${ }^{1}$ Professor da rede pública estadual do Espírito Santo. Mestre em Estudos Linguísticos pela Universidade Federal do Espírito Santo. E-mail: marciofaverofiorin2@gmail.com.

2 Professora aposentada voluntária da Universidade Federal do Espírito Santo, atuando também no PROFLETRAS/IFES. Doutorado em Linguística pela Universidade Federal de Minas Gerais. Atualmente cursa o segundo doutorado em Letras na Pontifícia Universidade Católica de Minas Gerais, com bolsa Capes. E-mail: eponzoperes@gmail.com.
} 


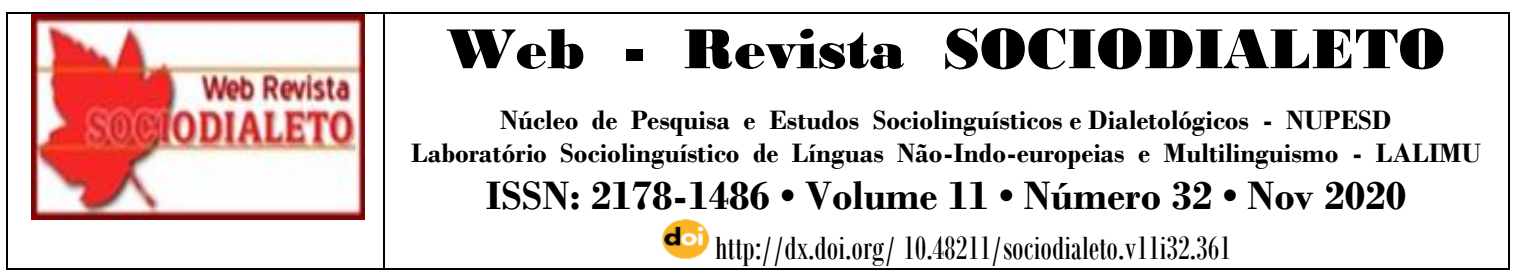

conclude that a work that supports school agents is necessary, through continuous education, so that cultural and linguistic diversity can be respected and valued by schools.

KEYWORDS: Language contact. Italian immigration in Alfredo Chaves. Espírito Santo. Venetian language. Linguistic substitution. Educational system.

\section{Introdução}

Os contatos étnicos e linguísticos marcaram a história do Espírito Santo. Primeiramente entre os próprios indígenas. Em seguida, entre eles e os portugueses. Posteriormente, chegaram os africanos escravizados e, por fim, os imigrantes, que vieram sobretudo do continente europeu: a partir de 1847, os germânicos; e, no último quartel do século XIX, os italianos (MOREIRA; PERRONE, 2007; CONDE, 2009; CAMPOS, 2011). Além deles, muitos brasileiros de outras regiões se fixaram no estado: fluminenses, cearenses, baianos, sergipanos e mineiros. (DADALTO; BENEDUZI, 2020).

As razões para a vinda dos europeus para o Brasil são várias, geralmente relacionadas à situação política, econômica e social tanto da Europa quanto do Brasil, e não foi diferente com respeito ao Espírito Santo $^{3}$. Os imigrantes chegados à Província se fixaram principalmente nas regiões montanhosas do Centro-Sul, cobertas de mata virgem. Ali, devido ao isolamento inicial, eles puderam manter suas culturas e suas línguas. Atualmente, no estado, algumas línguas minoritárias ${ }^{4}$ ainda são usadas para a comunicação diária, como o pomerano (BREMENKAMP, 2014; KÜSTER, 2018) e o hunsrückisch (KLIPPEL-MACHADO, 2018), mas não se tem conhecimento de comunidades onde as línguas italianas sejam faladas pela população mais jovem (PERES, 2014).

Neste estudo, não será possível detalharmos os fatores que levam uma língua minoritária a ser mantida ou abandonada por seus falantes, mas pretendemos analisar

\footnotetext{
3 A história social dos contatos linguísticos no Espírito Santo já foi tema de artigos e dissertações de Mestrado. Vejam-se, por exemplo: Bremenkamp (2014); Peres (2014); Cominotti (2015); Peres, Dadalto e Cominotti (2015) etc.

${ }^{4}$ Seguindo o Inventário Nacional da Diversidade Linguística (INDL), utilizamos neste trabalho os termos língua minoritária e língua de imigração.
} 


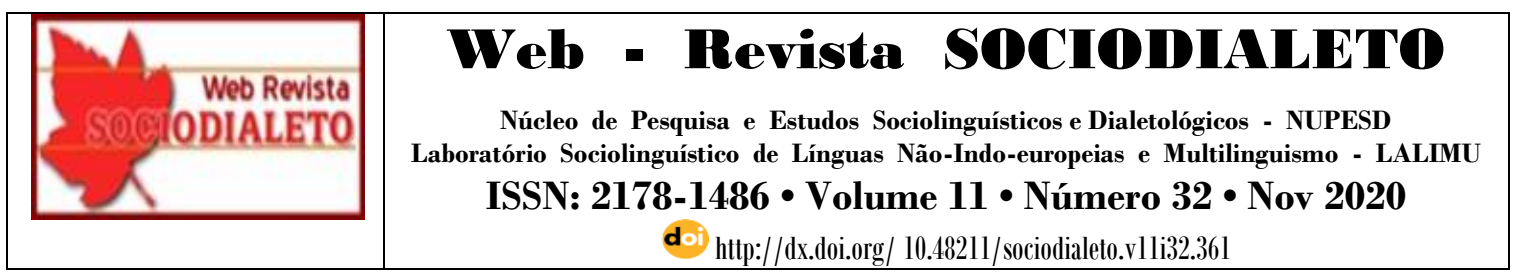

especificamente uma das razões da substituição da língua vêneta pela portuguesa: a atuação das instituições escolares, as quais, durante e até mesmo após o Estado Novo do Presidente Getúlio Vargas, seguiram as determinações governamentais de proibir o uso das línguas estrangeiras no país e incentivar o uso do português. Para realizar essa análise, lançamos mão de dados gerados por entrevistas feitas na Sede e em Santa Maria de Ibitiruí, comunidades de Alfredo Chaves (ES), um município com forte presença de descendentes de imigrantes italianos.

Para apresentar nossas reflexões, este trabalho foi dividido em cinco seções, além desta introdução. Na seção 2, consta um resumo do referencial teórico que embasou as nossas análises. Em seguida, na seção 3, descrevemos os procedimentos metodológicos adotados neste estudo. Na seção 4, refletimos sobre a atuação da escola para a imposição do monolinguismo em português nas duas comunidades estudadas, exemplificando esse processo com depoimentos de (ex-)professores e ex-estudantes, que relatam sua vivência escolar. E, por fim, na seção 5, tecemos nossas considerações finais.

\section{0 sistema educacional e a substituição linguística}

A manutenção ou a substituição de uma língua minoritária se dá por fatores políticos, sociais, demográficos e culturais, que atuam em conjunto, como a transmissão intergeracional; o número absoluto de falantes e sua proporção entre a população total; os contatos (in)frequentes com outros falantes e com sua terra natal; o sentimento de identificação - ou não - com a pátria ancestral; as crenças linguísticas dos grupos minoritário e majoritário; os casamentos intra/interétnicos; a classe social dos falantes da língua minoritária; o status da língua; o caráter permanente ou temporário da imigração etc. ${ }^{5}$ Assim, os processos de manutenção ou de substituição linguística irão depender do

\footnotetext{
${ }^{5}$ Os fatores de manutenção/substituição linguística constam da vasta bibliografia disponível do Contato Linguístico, como: Appel e Muysken (1996), Fasold (1996), Baker e Jones (1998), Winford (2003), o Documento Language Vitality and Endangerment (UNESCO, 2003), Coulmas (2005), Matras (2009), Montrul (2013), Abtahian (2019), Brenzinger (2019) etc.
} 


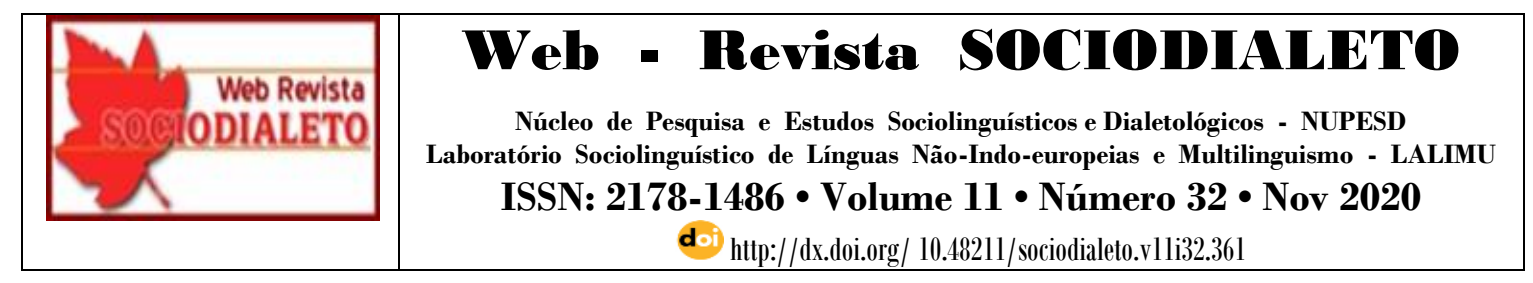

comportamento dos falantes individualmente, da comunidade minoritária e da sociedade em que estes se encontram.

É fato que os imigrantes que chegarem a outro país com uma língua diferente da sua precisarão se comunicar com os habitantes locais. É natural, igualmente, o desejo de ascensão social por parte deles e de seus descendentes. Portanto, essas pessoas precisarão aprender a língua falada no país onde se fixarem, para a sua integração à sociedade local. Por outro lado, os imigrantes não precisam, necessariamente, abandonar sua língua ancestral em prol de uma outra. Eles podem decidir tornar-se bilíngues, mas não é isso o que geralmente ocorre, pois já os netos de imigrantes normalmente são monolíngues na língua majoritária do país de acolhimento ${ }^{6}$.

Como dissemos, os fatores de manutenção ou de substituição de uma língua minoritária são vários. Neste trabalho, pretendemos analisar a influência da escola para a substituição linguística em duas comunidades de Alfredo Chaves (ES). Baker e Jones (1998, p. 182) classificam o contexto escolar entre os fatores culturais favorecedores da manutenção ou da substituição linguística ${ }^{7}$. Entre os dez fatores culturais listados pelos autores, o sistema educacional aparece em três. Segundo eles, uma língua minoritária tenderá a ser substituída pela majoritária se:

i) na sociedade, não existirem instituições que veiculem a língua minoritária (ex.: escolas, organizações comunitárias, mídias, atividades de lazer etc.);

ii) a educação na língua majoritária for enfatizada nas escolas; e

iii) a educação na língua majoritária tiver aceitação por parte do grupo minoritário.

Essa relevância da educação também é evidenciada pelo Documento Language Vitality and Endangerment (UNESCO, 2003). O Documento, elaborado por um grupo de especialistas em línguas ameaçadas de extinção, apresenta considerações teóricas e

\footnotetext{
${ }^{6}$ Cf., por exemplo, Weinreich (1970 [1953]) sobre a Lei da terceira geração.

7 A expressão usada originalmente pelos autores é language loss (BAKER; JONES, 1998, p. 182); entretanto, optamos pela expressão substituição linguística.
} 


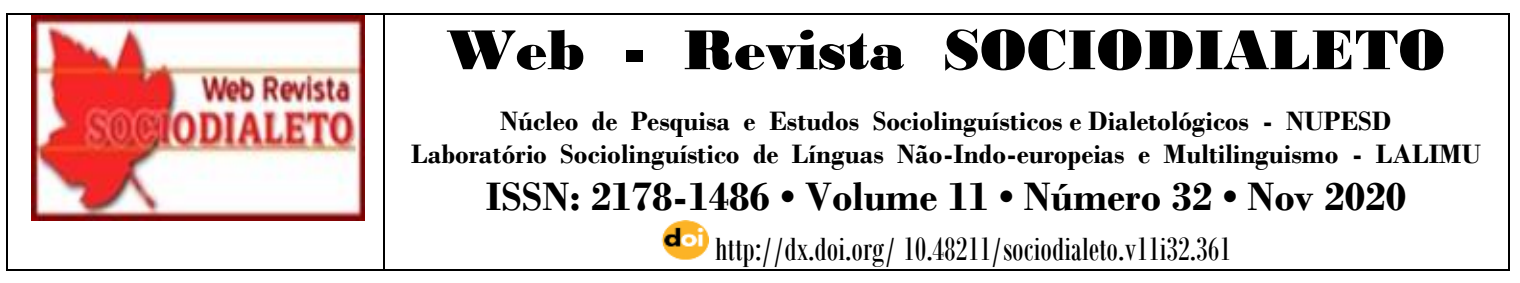

práticas acerca dessas línguas, apontando caminhos para reverter o seu desaparecimento. Segundo o Documento (UNESCO, 2003, p. 02), a ameaça a uma língua tem causas externas - a subjugação militar, econômica, religiosa, cultural ou educacional - e internas, como as atitudes dos falantes em relação à sua própria língua. Entretanto, as forças internas frequentemente têm suas raízes nas pressões externas.

O Documento também indica seis fatores que possibilitam avaliar os níveis de vitalidade de uma língua, dois fatores que avaliam as atitudes em relação à língua ameaçada e um que avalia a urgência de sua documentação. Entretanto, os elaboradores do Documento (UNESCO, 2003, p. 07) advertem que nenhum dos fatores pode ser usado isoladamente para se realizar essa avaliação. O Documento afirma ainda que o apoio a uma língua ameaçada - e sua comunidade de falantes - passa, em primeiro lugar, pela tarefa de linguistas, educadores e ativistas em documentar a língua e, em seguida, pela participação ativa em programas educacionais: treinamento em linguística básica e em métodos e técnicas pedagógicas para professores da língua minoritária; e apoio e desenvolvimento de uma política educacional em prol da língua ameaçada ${ }^{8}$.

Quanto aos fatores de avaliação da vitalidade linguística, os elaboradores apontam a necessidade do uso da língua minoritária nas instituições educacionais, assim como em outros domínios já existentes e nos novos, para a sua manutenção (cf. Fatores 4 e 5, p. 912). Os especialistas também frisam a importância de haver materiais para a educação na língua ameaçada. Com respeito aos fatores que avaliam as atitudes linguísticas, o Documento frisa a relevância das políticas estatais para as línguas minoritárias: "A ideologia linguística de um Estado pode inspirar as minorias linguísticas a se mobilizarem em direção à manutenção de suas línguas ou podem forçá-las ao seu abandono"9 (UNESCO, 2003, p. 12). Assim, se um governo enxergar a existência de línguas minoritárias em seu território como um risco à unidade ou à soberania nacional, poderá desencorajar ou mesmo proibir seu uso. Vemos, assim, que a política de um país pode ir

\footnotetext{
${ }^{8}$ O Documento traz outras considerações a respeito do ensino de línguas minoritárias, mas não será possível aprofundarmo-nos aqui nessas questões.

9 No original: "The linguistic ideology of a state may inspire linguistic minorities to mobilize their populations toward the maintenance of their languages, or may force them to abandon them".
} 


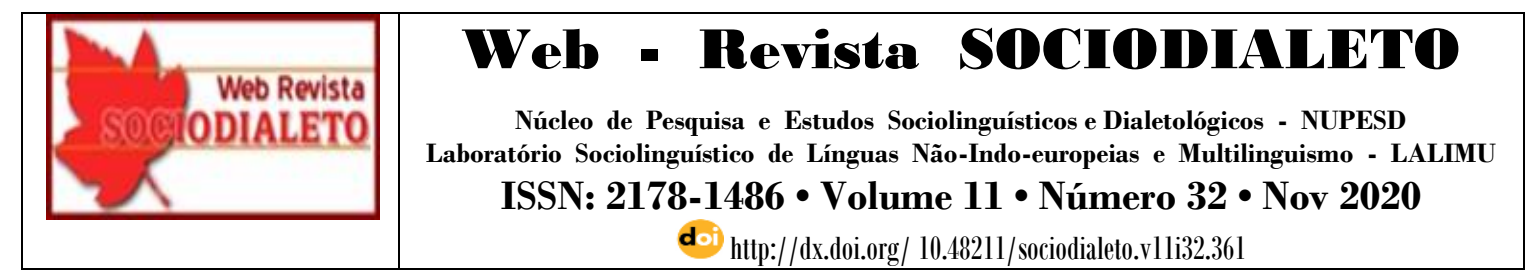

de um extremo a outro: tanto haver proteção a todas as línguas faladas no país, com a determinação do status oficial a todas elas, quanto haver a instituição de uma única língua como oficial e a proibição das demais.

No Brasil, as políticas públicas nem sempre favoreceram as línguas minoritárias; pelo contrário, elas receberam muito mais censura do que apoio. Exemplo do que dizemos foi o Estado Novo, do governo do Presidente Getúlio Vargas (1937-1945). Esse período foi marcado por um forte movimento nacionalista em que o Estado procurou controlar todas as formas de liberdade dos estrangeiros que estavam no país e, principalmente, impôs o abandono de sua identidade e de sua língua para tornar-se parte da nova nação.

Durante a Campanha Nacionalista de Vargas, visando-se à regulamentação e à proibição das manifestações políticas e culturais dos imigrantes e seus descendentes, foram homologados os Decretos-lei $n^{\circ} 406$, de 04 de maio de 1938; o de $n^{\circ} 3.010$, de 20 de agosto de 1938, que regulamentava o primeiro; e o de $\mathrm{n}^{\circ} 1.545$, de 25 de agosto de 1939. No tocante ao Decreto $n^{\circ} 406 / 1938$, todo o aparato do Estado - incluindo-se o sistema educacional - foi usado para reprimir as línguas dos imigrantes. Entre as diversas medidas tomadas por meio desse Decreto, instituía-se que as línguas dos imigrantes deveriam ser banidas da escola, cabendo a esta o ensino apenas da língua portuguesa: "os professores, a língua, os livros, e até mesmo noções sobre as instituições políticas deviam ser do país. [...] Com isso ele [Vargas] garantia um aparato educacional nacionalista" (ORLANDI, 2005, p. 29).

Já o Decreto nº 1545/1939, segundo Orlandi (2005), intensificou a censura e as medidas de nacionalização dos imigrantes no país, o que repercutiu diretamente sobre suas línguas. A política linguística da época era o ensino e a veiculação unicamente da língua portuguesa. Orlandi (2005, p. 31) afirma que, "em nome da língua nacional podiase exercer forte repressão linguística. O estrangeiro não era um cidadão. E era sua língua o documento desta exclusão". De acordo com a autora, mesmo após a volta da democracia, em 1946, a comissão formada para nomear a língua do Brasil a designa língua portuguesa. 


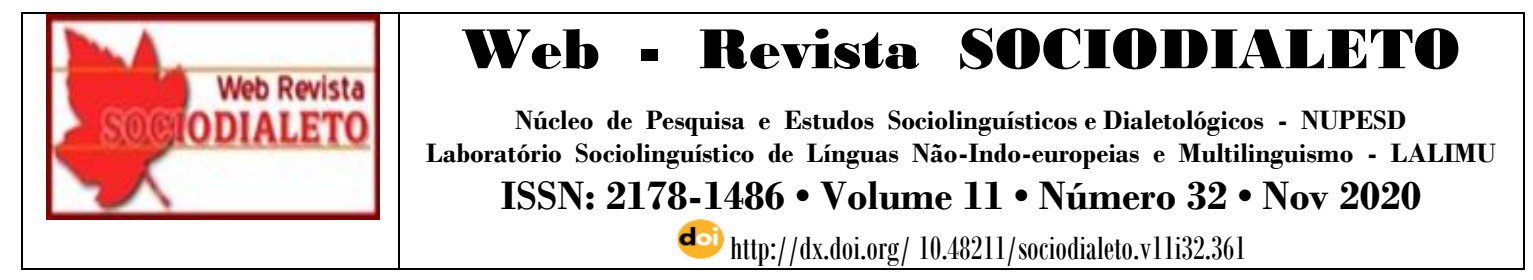

A consolidação dos decretos da era Vargas foi crucial para determinar a imagem de uma nação unificada, procurando implantar a ideia de um país monolíngue (CRUZ, 2015). A estratégia do governo de impor seus propósitos se deu a partir dos meios de comunicação e do sistema educacional ${ }^{10}$. Este contribuiu com a elaboração e disponibilização de cartilhas que continham na íntegra as leis para os estudantes, além, como dissemos, do ensino unicamente do português.

Ainda com relação à escola, Pagani (2012) afirma que, mesmo antes da Campanha Nacionalista, a escola nitidamente privilegiava a classe burguesa e participava da divulgação dos valores elitistas. Embora houvesse tentativas de se criarem escolas para os filhos dos imigrantes, com o objetivo tanto de integrá-los à sociedade brasileira quanto de preservar a sua língua ancestral, esse projeto não vingou devido às pressões sociais da época. Nesse período, a sociedade brasileira era comandada pelos grandes proprietários de terras, que administravam a economia e determinavam as leis que deveriam ser seguidas pelos demais.

Por outro lado, cremos que essa situação não mudou substancialmente com o passar dos anos. Bagno (2012) afirma que o cenário linguístico - e diríamos escolar ainda sofre as pressões sociais exercidas pela elite:

Infelizmente, não podemos deixar de reconhecer que, numa sociedade muito hierarquizada como a brasileira e extremamente desigual no tocante à distribuição dos bens materiais, culturais e sociais, são as elites urbanas mais letradas que ditam o que é certo ou errado, não só em termos de língua, mas em todos os comportamentos, crenças, gostos etc. Assim, a ascensão do normal ao normativo depende da aceitação desse normal no interior dessas camadas sociais privilegiadas (BAGNO, 2012, p. 26).

Segundo Bagno (2012), criou-se o pressuposto do português chamado culto como língua ideal, não se levando em consideração a realidade linguística da sociedade

\footnotetext{
${ }^{10}$ Em Oliveira (2016), o autor trata de outra forma de controle e de censura das línguas dos imigrantes: os censos de 1940 e 1950, que procuravam identificar quem falava quais línguas ancestrais, a fim de que estas fossem reprimidas.
} 


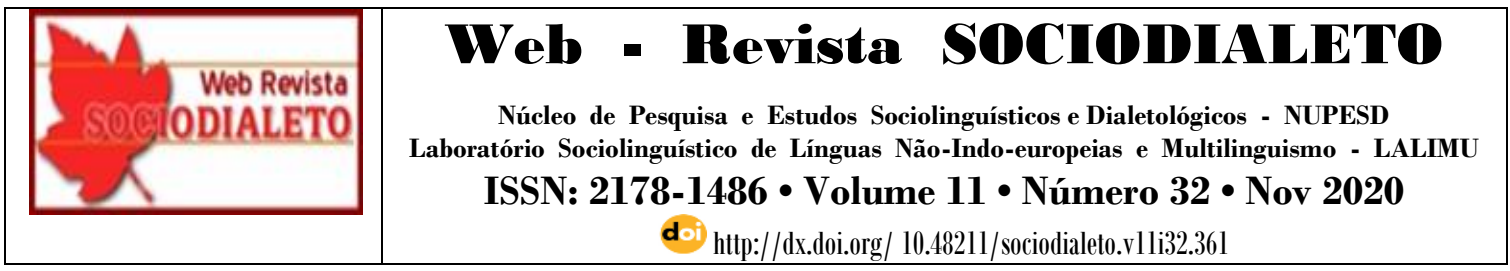

brasileira. Essa situação fez com que surgissem critérios dicotômicos para qualificar as variedades linguísticas: certas vs. erradas, bonitas vs. feias, cultas vs. ignorantes. Dessa forma, o que diferir da ideia de monolinguismo, da gramática e de livros didáticos - e acrescentamos que aí se incluem as línguas minoritárias ou seus traços presentes no português - será visto como feio e/ou errado e, por conseguinte, seus falantes são atingidos pelo preconceito. Veremos adiante como isso se deu com nossos informantes, sendo um forte motivo para o seu sentimento de vergonha da língua ancestral.

Por outro lado, cremos que o professor precisa ter um olhar crítico sobre a presença da diversidade no currículo escolar, pois, em sua função de formadores de cidadãos, é indispensável o cuidado com o outro, procurando meios que possibilitem uma discussão sobre a diversidade linguística. Numa situação de bi ou multilinguismo, de acordo com García (2008, p. 389), os profissionais da educação "precisam ter um conhecimento especializado sobre as lutas sociais, políticas e econômicas em torno das línguas, sobre as práticas pedagógicas que envolvem o bilinguismo e sobre o bilinguismo em si" ${ }^{11}$. Em outras palavras, a compreensão do contexto social é muito relevante para o processo de ensino de línguas, e esses desafios apontam para mais uma política pública: a necessidade de formação de professores contínua e de qualidade.

Isto posto, temos que a escola, no contexto histórico brasileiro, atuou como mecanismo de reprodução dos ideais dominantes, e isso ainda se dá, ou seja, a escola segue o que a sociedade impõe. Por isso, fazer um trabalho de respeito e de valorização das diferenças culturais e linguísticas dentro do ambiente escolar se torna importante para a manutenção das línguas minoritárias. Na seção de Análise dos Dados, trazemos depoimentos de (ex-)professoras e de ex-alunos que ilustram os seus ambientes de sala de aula e que mostram situações de preconceito com relação à fala do outro, o que contribuiu para a substituição do vêneto pelo português nas comunidades analisadas.

\footnotetext{
11 No original: “... [all teachers] need to have specialized knowledge about the social, political, and economic struggles that surround the languages, about pedagogical practices surrounding bilingualism, and about bilingualism itself."
} 


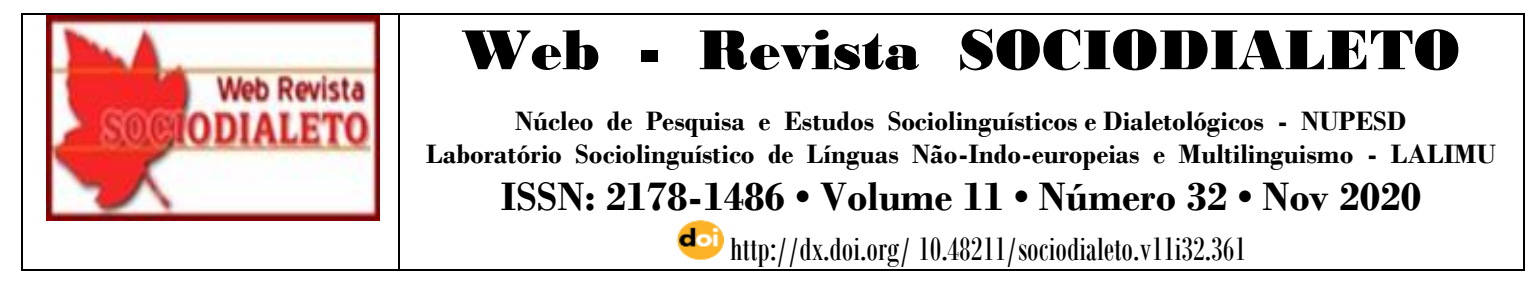

\section{Procedimentos metodológicos}

Nossa pesquisa teve lugar em duas localidades de Alfredo Chaves: a Sede e a comunidade rural de Santa Maria de Ibitiruí. A população estimada do município em 2018 era de 15.082 habitantes (IBGE, 2019), sendo que a Sede contava com 7.073 moradores e Santa Maria, com cerca de 300 pessoas, segundo dados fornecidos pela igreja católica local, que congrega todos os habitantes da comunidade. A Sede conta com três escolas de ensino básico, sendo duas municipais de Ensino Fundamental I e II, e uma estadual que oferece todos os níveis da educação básica (PMAC, 2018). Santa Maria de Ibitiruí, por sua vez, nunca contou com escola. Para estudar, as crianças e adolescentes se deslocavam e ainda se deslocam até a escola do distrito de Ibitiruí, que dista três quilômetros de Santa Maria. Atualmente, os estudantes contam com transporte da Prefeitura, mas, na infância da maioria de nossos informantes, o percurso deveria ser feito a pé.

Para a geração dos dados, foram feitas dez entrevistas com moradores da Sede e vinte com moradores de Santa Maria do Ibitiruí, todos descendentes de imigrantes vênetos. As entrevistas - com duração entre uma e duas horas - foram realizadas nas residências dos informantes por um dos autores deste trabalho, que nasceu e reside em Santa Maria de Ibitiruí e que trabalha na Sede do município. Foi utilizado um roteiro de perguntas sobre a história do local de moradia e da família, sobre o porquê de a língua dos antepassados ter deixado de ser falada e sobre as lembranças de escola, tais como as possíveis críticas recebidas quanto à sua forma de falar.

Além desses sujeitos, entrevistamos cinco agentes escolares, em ambas as localidades, sendo três professoras do Ensino Fundamental I e duas pedagogas que atuaram e/ou ainda atuam na profissão. Para essas entrevistas, elaboramos perguntas direcionadas às práticas de sala de aula: como eram e como são tratadas, pelo sistema 


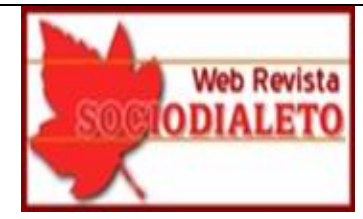

\section{Web - Revista SOCIODIALETO}

Núcleo de Pesquisa e Estudos Sociolinguísticos e Dialetológicos - NUPESD Laboratório Sociolinguístico de Línguas Não-Indo-europeias e Multilinguismo - LALIMU ISSN: 2178-1486 • Volume $11 ・$ Número $32 \bullet$ Nov 2020 doi http://dx.doi.org/ 10.40211/sociodialeto.v1li32.361

público de ensino, as línguas de imigração e o português falado com traços de outra língua, ou seja, como é tratada a diversidade linguística.

Ao final de cada gravação, os informantes assinaram um Termo de Consentimento Livre e Informado, por meio do qual pudemos trabalhar com as informações prestadas. Os quadros a seguir apresentam as características dos sujeitos deste estudo, dispostos em ordem alfabética das iniciais de seus nomes.

Quadro 1 - Características sociais dos informantes - Sede de Alfredo Chaves

\begin{tabular}{|c|c|c|c|}
\hline INFORMANTES & IDADE & SEXO & ESCOLARIDADE \\
\hline ANA & 91 & $\mathrm{~F}$ & $2^{\mathrm{a}}$ série \\
\hline ARL & 67 & M & $6^{\mathrm{a}}$ série \\
\hline CAR & 54 & M & $3^{\mathrm{a}}$ série \\
\hline FAT & 55 & $\mathrm{~F}$ & $7^{\mathrm{a}}$ série \\
\hline JOS & 68 & M & $7^{\mathrm{a}}$ série \\
\hline LEA & 58 & M & $5^{\mathrm{a}}$ série \\
\hline MAR & 72 & M & $7^{\mathrm{a}}$ série \\
\hline MRI & 52 & $\mathrm{~F}$ & $5^{\mathrm{a}}$ série \\
\hline NAT & 66 & $\mathrm{~F}$ & $6^{\mathrm{a}}$ série \\
\hline ROS & 64 & $\mathrm{~F}$ & $3^{\mathrm{a}}$ série \\
\hline
\end{tabular}

Fonte: Autor 1 (2019)

Quadro 2 - Características sociais dos informantes - Santa Maria de Ibitiruí

\begin{tabular}{|c|c|c|c|}
\hline INFORMANTES & IDADE & SEXO & ESCOLARIDADE \\
\hline ALE & 86 & $\mathrm{M}$ & $1^{\mathrm{a}}$ série \\
\hline ANT & 69 & $\mathrm{M}$ & $2^{\mathrm{a}}$ série \\
\hline AUX & 52 & $\mathrm{~F}$ & $6^{\mathrm{a}}$ série \\
\hline DOL & 64 & $\mathrm{~F}$ & $2^{\mathrm{a}}$ série \\
\hline ELI & 49 & $\mathrm{M}$ & $6^{\mathrm{a}}$ série \\
\hline
\end{tabular}




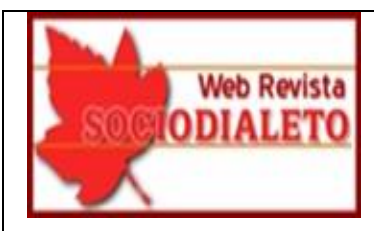

\section{Web - Revista SOCIODIALETO}

Núcleo de Pesquisa e Estudos Sociolinguísticos e Dialetológicos - NUPESD Laboratório Sociolinguístico de Línguas Não-Indo-europeias e Multilinguismo - LALIMU ISSN: 2178-1486 • Volume 11 • Número 32 • Nov 2020 doi http://dx.doi.org/ 10.4821l/sociodialeto.vlli32.36l

\begin{tabular}{|c|c|c|c|}
\hline ELZ & 61 & $\mathrm{~F}$ & $6^{\mathrm{a}}$ série \\
\hline JAC & 44 & $\mathrm{~F}$ & $4^{a}$ série \\
\hline JOA & 55 & M & $6^{\mathrm{a}}$ série \\
\hline LEL & 72 & $\mathrm{~F}$ & $2^{\mathrm{a}}$ série \\
\hline LUI & 84 & M & $5^{\mathrm{a}}$ série \\
\hline LZA & 44 & $\mathrm{~F}$ & $4^{\mathrm{a}}$ série \\
\hline MAL & 68 & M & $1^{\mathrm{a}}$ série \\
\hline MRN & 48 & $\mathrm{~F}$ & $4^{\mathrm{a}}$ série \\
\hline NSL & 78 & M & $1^{\mathrm{a}}$ série \\
\hline REN & 60 & M & $5^{\mathrm{a}}$ série \\
\hline RSL & 84 & M & $1^{\mathrm{a}}$ série \\
\hline SAN & 44 & M & $8^{\mathrm{a}}$ série \\
\hline SIM & 20 & M & $3^{\circ}$ ano $-\mathrm{EM}$ \\
\hline VAL & 58 & M & $7^{\mathrm{a}}$ série \\
\hline ZAU & 86 & $\mathrm{~F}$ & $2^{\mathrm{a}}$ série \\
\hline
\end{tabular}

Fonte: Autor 1 (2019).

Quadro 3 - Características sociais das agentes escolares - Sede e Santa Maria de Ibitiruí

\begin{tabular}{|c|c|c|c|}
\hline INFORMANTES & IDADE & ESCOLARIDADE & PROCEDÊNCIA \\
\hline LA - P1 12 & 49 & Magistério - professora de língua portuguesa & Sede \\
\hline MA - P2 & 64 & Magistério - professora de séries iniciais e \\
pedagoga 13 & Santa Maria de Ibitiruí \\
\hline EU - P3 & 73 & Magistério - professora de séries iniciais & SMI \\
\hline MA - P4 & 69 & Magistério - professora de séries iniciais & Sa \\
\hline
\end{tabular}

12 Designamos as agentes escolares por P1, 2, 3, 4 e 5, para sua melhor identificação na subseção 4.1.

13 As informantes P2 e P5 atuaram por um período em sala de aula e depois assumiram o cargo de pedagogas. Por isso, no quadro colocamos as duas funções. 


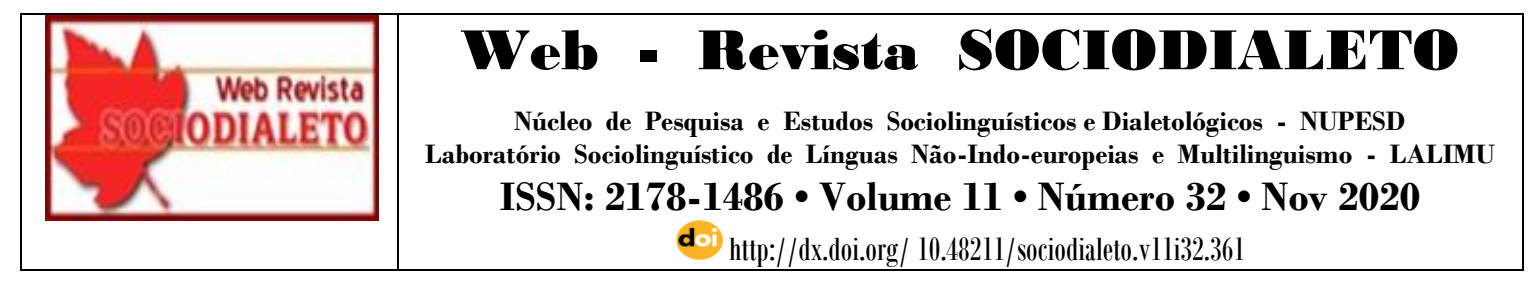

\begin{tabular}{|c|c|c|c|}
\hline $\mathrm{RE}-\mathrm{P} 5$ & 56 & $\begin{array}{c}\text { Magistério - professora de séries iniciais e } \\
\text { pedagoga }\end{array}$ & SMI \\
\hline
\end{tabular}

Fonte: Autor 1 (2019).

As entrevistas, além da literatura da área, possibilitaram as análises dos dados, que são realizadas a seguir.

\section{Análise de dados: a atuação da escola na substituição linguística}

A fim de procedermos à análise dos dados, dividimos esta seção em duas partes, trazendo a perspectiva docente (4.1) e discente (4.2) quanto ao papel da escola no processo de substituição linguística. O objetivo desta análise é compreender a realidade escolar de ambas as comunidades, especialmente os mecanismos adotados para a imposição da língua oficial, o português.

\subsection{A perspectiva docente}

Nesta subseção, procuramos entender como os profissionais da educação viam e veem a língua e a cultura dos imigrantes, além de como trataram e tratam, em sala de aula, a diversidade linguística. Para iniciar esta discussão, vejamos os depoimentos de duas docentes:

Excerto 1 - Professora 1 (P1) - Sede:

Sou formada no antigo magistério e dei aula de língua portuguesa na rede pública do município. [...] Ensinava aquilo que os documentos e o governo pediam. Ensinava a norma padrão, de como escrever um bom texto. Procurava ensiná-los para serem boas pessoas. [...] Tinha alunos bons e fracos e tinha aqueles que falavam tudo errado e eu chamava a atenção para aprender.

Excerto 2 - P5 - SMI: 


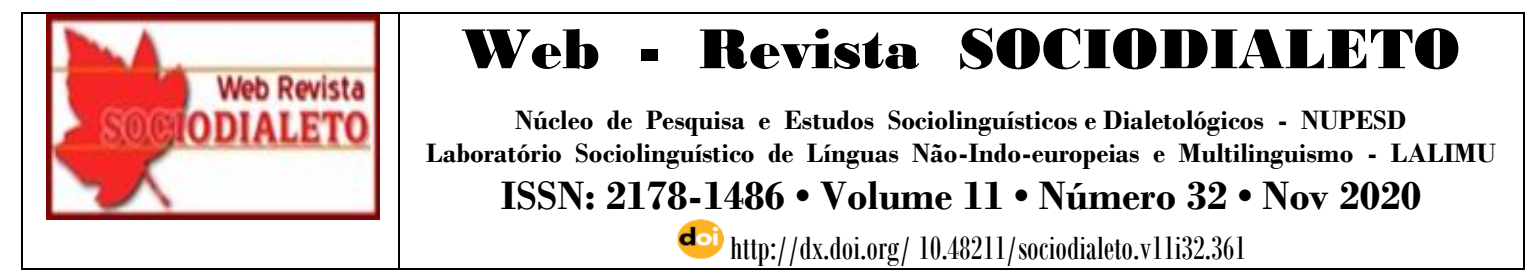

Dava aula para as crianças no ensino fundamental desde 1980 e lhes ensinava as matérias básicas, como português e matemática. Procurava manter a ordem e ensinar o que estava somente nos livros. [...] O português passou a ser mais cobrado nas séries iniciais. E eu cobrava muito a ortografia e o jeito que eles falavam.

Ambos os depoimentos, podemos observar que as docentes têm a mesma opinião a respeito do ensino de língua: a variedade culta do português deveria ser trabalhada em sala de aula, seguindo-se os documentos oficiais e as leis vigentes à época. Dessa forma, ao pensarmos sobre qual deveria ser o espaço para o trabalho com a diversidade linguística, a resposta seria nenhum, pelo fato de as professoras estarem preocupadas apenas com o ensino normativo e a ordem - manter a sala quieta e a turma organizada. Para elas, a variação linguística não era uma questão a ser discutida entre os alunos.

As professoras também informam que, quando os alunos falavam errado ${ }^{14}$, elas chamavam a sua atenção. O falar errado, em comunidades colonizadas por imigrantes, significa que a linguagem das crianças apresentava traços das línguas dos antepassados no caso em questão, as variedades vênetas. Em síntese, a linguagem dos alunos era desaprovada. Portanto, observamos que havia uma sistemática cobrança do uso da variedade culta do português na língua oral dos estudantes, o que se contrapõe com um ensino sensível às diferenças, que leve em conta a diversidade linguística e que leve o aluno a aprender a variedade de prestígio da língua portuguesa sem desmerecer a sua própria variedade.

A fim de avaliarmos as atitudes das professoras em relação à língua dos imigrantes e sua influência no português, fizemos essa pergunta durante as entrevistas. Somente duas docentes - P3, da zona rural, e P4, da Sede - disseram que se tratava de um traço característico da linguagem das famílias e que, por isso, o professor tinha que levar em

\footnotetext{
14 Apesar da importância da discussão sobre a noção de erro e de variação linguística no ensino de Língua Portuguesa, neste trabalho, por limitação de espaço, não será possível abordar esses aspectos.
} 


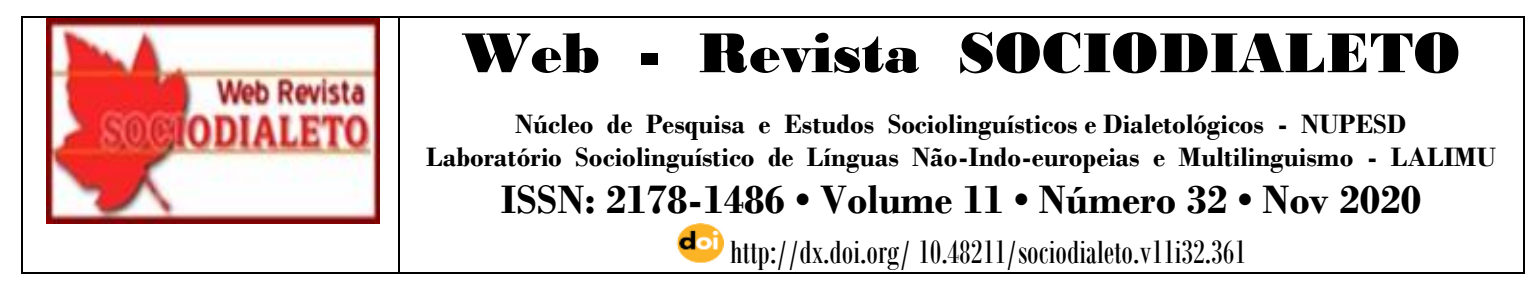

consideração o contexto social da comunidade. Parte dos depoimentos encontram-se a seguir:

Excerto 3 - P3 - SMI:

Como convivo com a comunidade, sei que o jeito de falar deles é característico da própria comunidade e que não adianta insistir em corrigir, pois é de família. A única coisa que faço é mostrar para eles o que está errado, ou seja, o que foge das normas da língua portuguesa, como grafia, pronúncia, concordância.

Excerto 4 - P4 - SMI:

Cada sujeito possui sua essência, o trabalho da escola não é corrigir o jeito de falar, mas prepará-los para o meio social. Também sei que o jeito de falar vem de família e isso não tem como corrigir.

Vamos que P3 corrigia o que ela considerava ser um erro - a influência da língua de imigração na pronúncia do português -, como evidenciam as últimas duas linhas do excerto 3 e os depoimentos das outras profissionais, a seguir.

Excerto 5 - P2 - Sede:

Naquele tempo o ensino era mais rígido e os professores cobravam muito mais, assim como eu fazia. Seguia aquilo que o governo mandava e a base das aulas eram as cartilhas. A escrita, a fala e as noções básicas de cada disciplina eram coisas que tinham que estar na ponta da língua, decorados. Ai de quem me desobedecesse!

Excerto 6 - P3 - SMI: 


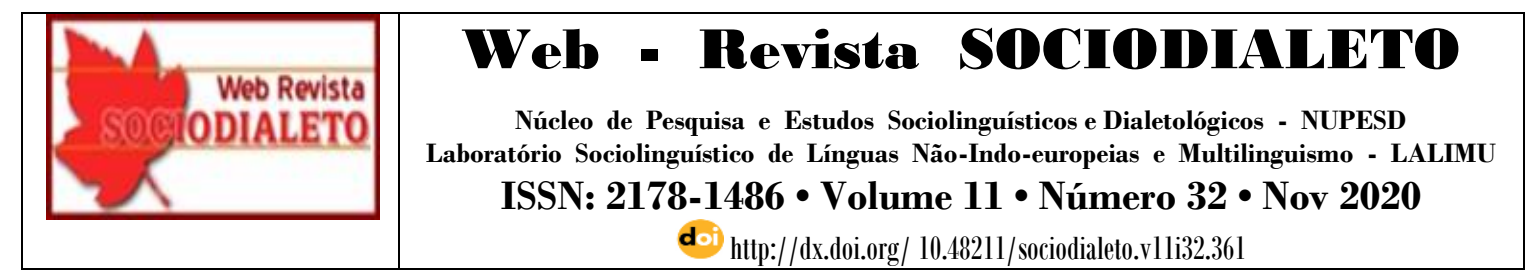

Eu cobrava muito a escrita correta e até mesmo o falar direito. Se a língua portuguesa é a ensinada na escola, tem que ser cobrada e aprendida corretamente. E te digo que até castigava os alunos se continuassem a fazer as coisas erradas.

As determinações governamentais com respeito ao ensino de Língua Portuguesa, além da pouca sensibilidade das docentes em relação à realidade sociolinguística dos alunos, fizeram com que a língua minoritária não tivesse nenhum espaço na escola. Tampouco aconteciam discussões acerca de sua influência no português falado pelas crianças. Mais ainda: quem ousasse desobedecer era castigado, como informam P2 e P3. Portanto, ao ser censurada, ficou evidente para as crianças que a língua de seus ancestrais não valia a pena ser falada e, por conseguinte, a sua substituição pelo português foi mais fácil.

Como expusemos, o Documento Language vitality and endangerment (UNESCO, 2003) destaca a importância das políticas linguísticas e do sistema educacional para a preservação de uma língua minoritária: a depender de como o governo do país receptor a considera, ela terá seu lugar na educação das crianças. No Espírito Santo, temos um exemplo dessa política, com o ensino da língua pomerana em alguns municípios do estado, que adotaram o Programa de Educação Pomerana (PROEPO) nas escolas de Ensino Fundamental I, conforme apontam as pesquisas de Hartuwig (2011) e Kuster (2015), realizadas em Santa Maria de Jetibá-ES. Essas pesquisadoras informam que o pomerano - língua materna de grande parte dos moradores do município - era e é usado na comunicação das pessoas em diversas situações - até mesmo nas mais formais -, inclusive pelo público juvenil, principalmente nas zonas rurais. Diante desse contexto, as escolas municipais, a partir de propostas educativas, incluíram o pomerano como disciplina, valorizando-o e estimulando a sua manutenção para as gerações futuras.

O exemplo de Santa Maria de Jetibá e de outros municípios do estado onde o PROEPO atua evidencia que a escola pode - e deve - respeitar, valorizar e proteger as línguas faladas em comunidades colonizadas por imigrantes. Com relação às línguas italianas em Alfredo Chaves, perguntamos tanto aos informantes da Sede quanto aos de 


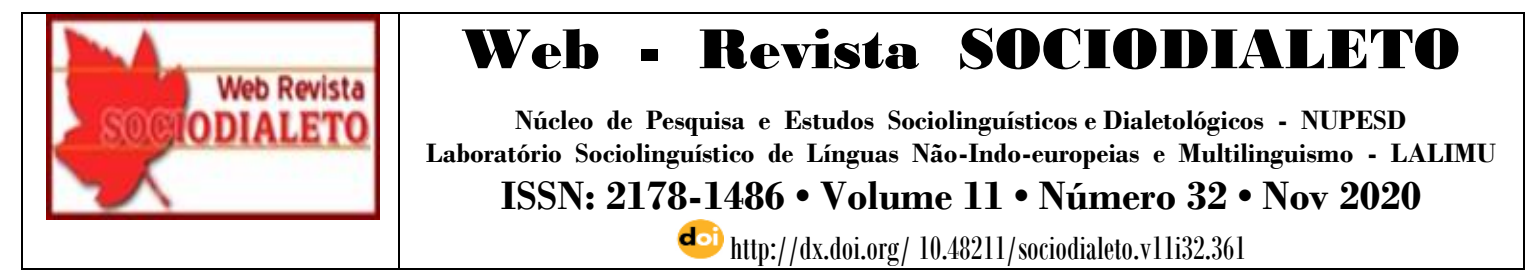

Santa Maria de Ibitiruí se conheciam, no passado ou atualmente, algum projeto de resgate da língua dos imigrantes nas escolas. As respostas, como já esperávamos, foram negativas. A única atividade voltada para a memória da imigração é a realização da Festitália, que ocorre todo mês de junho, no município. Essa festa é organizada por um pequeno grupo de moradores da Sede de Alfredo Chaves que desejam resgatar a história dos antepassados por meio de elementos culturais italianos, como a música, os jogos e a culinária.

$\mathrm{Na}$ próxima subseção, consta a análise do ambiente escolar com base nos depoimentos de ex-discentes, que narram as suas experiências e impressões com relação ao tratamento da diversidade linguística nas aulas de Português.

\subsection{A perspectiva discente}

Nesta subseção, analisamos a experiência escolar dos ex-estudantes: as políticas educacionais e as dificuldades enfrentadas por eles, como o rigor do ensino, a imposição do português e a discriminação sofrida por não falarem o português culto.

Excerto 7: NSL, 78, M, $1^{\text {a }}$ série, $\mathrm{SMI}^{15}$ :

Ninguém falava o italiano, na escola. A gente aprendia apenas o português.

Excerto 8: JOS, 68, M, $7^{\mathrm{a}}$ série, Sede:

\footnotetext{
${ }^{15}$ Nos excertos constam as características sociais dos informantes, nesta ordem: iniciais de seu nome, idade, sexo, escolaridade e procedência (Sede ou SMI).
} 


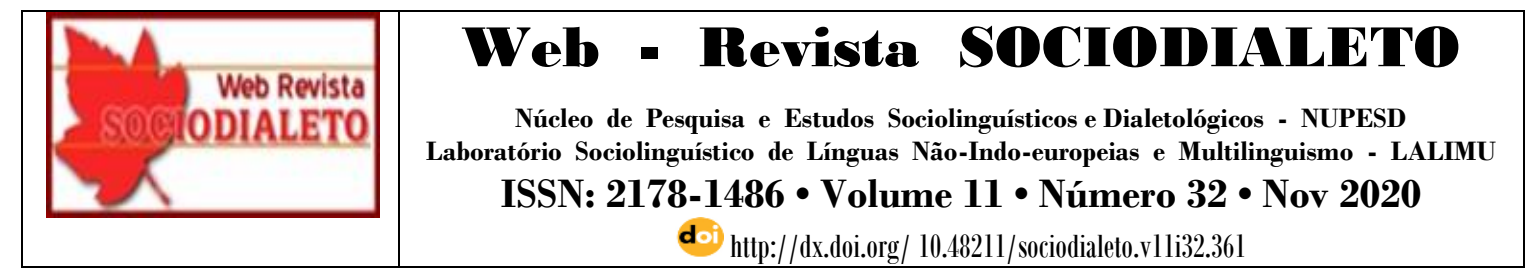

Eu sabia falar o dialeto, hoje não sei mais. Tinha vergonha porque misturava algumas palavras quando era mais jovem. Preferi falar o português, o que a gente aprendia na escola. E é a língua daqui.

Os excertos 7 e 8 evidenciam que o português era a única língua que tinha espaço na escola. No trecho a seguir, o rigor da professora e o medo dos alunos.

Excerto 9: ELZ, 61, F, 6ª série, SMI:

A gente ficava assustado na sala de aula e todos respeitavam muito a professora. Lembro que ela pedia para nós trazermos uma varinha bem bonita, que era colocada no canto da sala e também caroços de milho. Era para castigar a gente, se caso fizesse bagunça.

O depoimento acima indica claramente o sentimento de medo das crianças diante do rigor das professoras, que as castigavam por qualquer coisa que faziam. $\mathrm{O}$ excerto a seguir expõe outra experiência escolar:

Excerto 10: AUX, 52, F, $6^{\mathrm{a}}$ série, $\mathrm{SMI}$ :

As escolas antigamente eram diferentes das de hoje, começando pelo tamanho. Era menor e precisava caber muitos alunos. Não tinha merenda, não tinha transporte e o material era usado entre os próprios irmãos. $O$ ensino era bem puxado e a cobrança da professora era muito maior do que hoje. Tinha que falar o português correto, e as matérias que eram mais cobradas era o português e a matemática. A professora era severa e a gente tinha medo dela [...]. Lembro também que na escola existia uma cartilha de leis que o governo mandava. As professoras devem lembrar mais do que eu, e lá dizia que tinha que seguir as normas da escola e aprender aquilo que estava aí, no livro. 


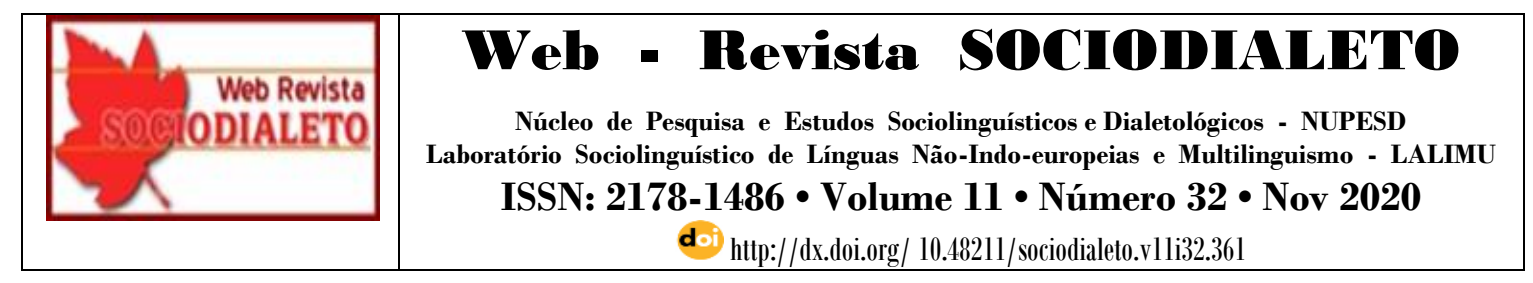

O excerto 10 confirma a atuação da escola como agente da imposição das leis e das normas do português culto. De acordo com a informante, além das disciplinas lecionadas, havia antigamente o estudo de uma cartilha de leis que o governo disponibilizava e exigia por parte dos educadores, em sala de aula. O conteúdo da cartilha versava sobre o ensino escolar e sobre noções básicas de cidadania, que os estudantes precisavam decorar na íntegra, pois eles eram avaliados por meio de exercícios orais. Esse fato comprova as pressões políticas e educacionais que as escolas brasileiras vivenciaram.

As atitudes das professoras possivelmente exerceram influência na aprendizagem tanto das lições da escola quanto da língua portuguesa sem qualquer marca vêneta. Ações como essas acabam por abrir espaço para o preconceito e a discriminação - que contribuem sobremaneira para a substituição linguística -, como é possível observar no depoimento a seguir, de um jovem de Santa Maria de Ibitiruí:

Excerto 11: SIM, 20, M, $3^{\circ}$ ano do EM - SMI:

Não fui um aluno muito estudioso, tirava a média na escola. Quando entrei pela primeira vez na escola, alguns alunos riam de mim pelo meu jeito de falar. Sei que falava tudo errado, mas eu tinha um jeito parecido com meu avô. Sei que isso é de família e por isso continuei falando. Dentro da escola, a professora brigava comigo pelo meu jeito de falar. Eu ficava triste, eu não gostava do que acontecia. Mas eu sou assim e depois de um tempo a professora viu que eu falava como meus pais, era coisa de família.

O informante SIM relata a humilhação pela qual passou quando iniciou seus estudos, fato este que aconteceu mais recentemente. A professora não compreendia - ou não queria compreender - que a forma de falar do jovem apenas trazia traços da língua dos antepassados do estudante, o que marcava a identidade de sua família e de seu grupo social. O depoimento 9, acima, evidencia a recriminação contra os traços vênetos no 


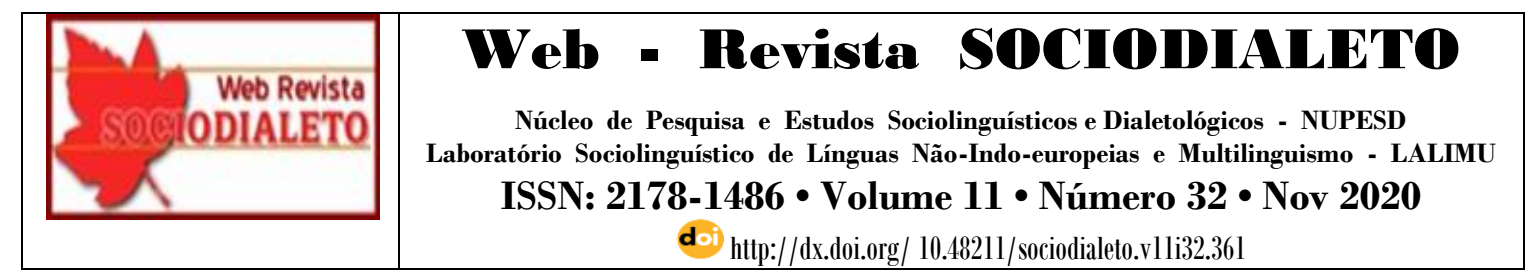

português dos falantes dessa comunidade rural, o que reforça o estigma contra a língua dos imigrantes.

Perguntamos ainda ao informante sobre o que pensava de sua linguagem, e sua resposta foi: "Falo mais carregado, como os italianos". Instado a explicar o que significava o falar mais carregado, hesitou e não soube responder. Entretanto, pelo fato de um dos autores deste trabalho pertencer à mesma comunidade do informante, sabemos que dois dos principais traços do vêneto presentes no português falado em Santa Maria de Ibitiruí são o ditongo nasal <ão> pronunciado [õ], como em piment[õ $]^{16}$, por exemplo; e o tepe em palavras como maca[r][õ], ca[r]oça e [r]ua. Essa é a fala carregada que, segundo o entrevistado, incomodava a professora.

No excerto a seguir, temos mais um exemplo de exclusão por parte de uma professora que também era intransigente com relação à linguagem dos alunos, a ponto de a informante ter desistido dos estudos:

Excerto 12: LZA, 44, F, $4^{\mathrm{a}}$ série, SMI:

Eu ia para a escola todos os dias, saía de casa a pé e ia até Ibitiruí. Era cansativo, não é igual hoje, que tem transporte. Chegando na escola ficava em silêncio e começava a aula. Era difícil fazer bagunça. Tinha pouco material e era difícil estudar. Eu e meus irmãos dividiamos os livros. A professora era brava, chamava atenção de tudo, até do jeito de falar. Eu não gostava muito dela e queria desistir da escola. Eu falava errado e ficava triste quando a professora chamava a atenção. Aí acabei indo para roça ajudar meus pais e não continuei os estudos. Mas acabei desistindo por achar tudo difícil e pela professora que brigava comigo.

Segundo nossos entrevistados, situações de preconceito linguístico eram comuns em sala de aula, principalmente na zona rural. A partir dos relatos apresentados, é possível verificar a atuação da escola para a eliminação de marcas da língua vêneta e, por

16 Para maiores informações a respeito da realização do ditongo nasal em Santa Maria de Ibitiruí, cf. Picoli-Meneghel (2015). 


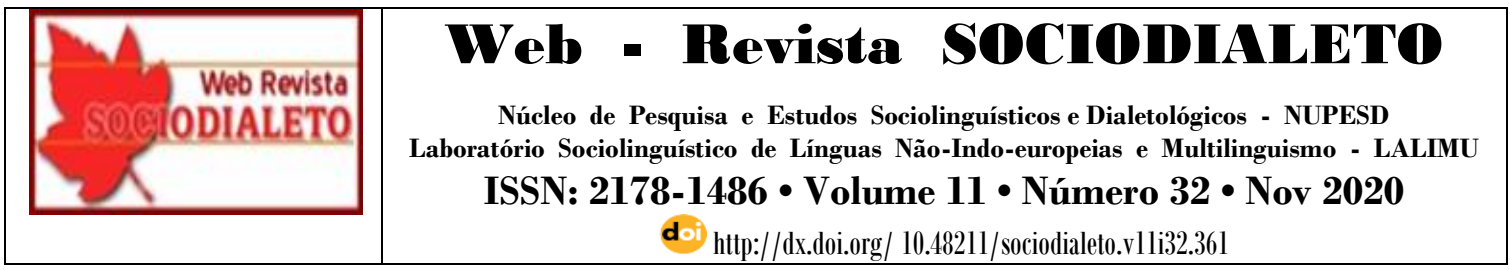

conseguinte, para a sua substituição pelo português, pois, se o sotaque era recriminado, a língua dos antepassados - que originava o sotaque - precisaria ser eliminada. Por outro lado, a linguagem da zona urbana não apresenta a mesma influência da língua ancestral, devido aos constantes contatos com brasileiros. Assim, as situações de preconceito eram menos comuns.

Concluindo esta seção, constatamos que existem traços que marcam a identidade linguística de uma comunidade colonizada por imigrantes, e o interior do município de Alfredo Chaves apresenta essas particularidades na linguagem de seus moradores, por influência da língua dos imigrantes. Dessa forma, é preciso que os professores e outros agentes escolares conheçam a história da comunidade onde atuam, a fim de compreenderem e se sensibilizarem com a linguagem de seus alunos e da comunidade. Portanto, a instituição de ensino precisa atuar em favor da comunidade, acolhendo sua realidade cultural e linguística. É dessa forma que as línguas minoritárias poderão ter uma chance de continuar sendo faladas, e as comunidades poderão permanecer sendo bilíngues, se for esse o seu desejo.

\section{Considerações finais}

A revisão da literatura apresentada, os depoimentos dados pelos entrevistados e nossa experiência com diversas comunidades capixabas demonstram que o propósito de integração à sociedade brasileira por parte dos imigrantes e seus descendentes, especialmente nas zonas urbanas, assim como as políticas governamentais contra as línguas de imigração, incluindo-se aí as pressões por parte da escola, foram fundamentais para a substituição de muitas línguas minoritárias pelo português.

No tocante ao ambiente escolar, vimos que as características linguísticas e culturais dos alunos foram e são ignoradas, ainda mantendo-se a falsa ideia do monolinguismo do país, dando-se margem para que crianças e adolescentes fiquem expostos ao preconceito linguístico. Sobre este tema, é importante resgatar os resultados 


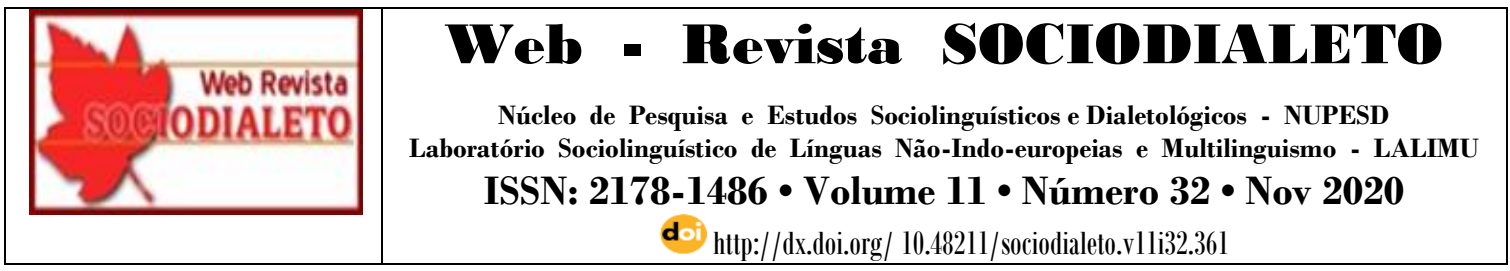

dos estudos de Picoli-Meneghel (2015) e Peterle (2017) realizados, respectivamente, nas comunidades de Santa Maria de Ibitiruí e de São Bento de Urânia, em Alfredo Chaves, que evidenciam que os traços da língua de imigração ainda estão presentes na linguagem de seus moradores. Por sua vez, Cominotti (2015) atestou que a fala dos moradores de São Bento de Urânia recebe avaliação negativa pelas pessoas de fora - e por algumas de dentro - da comunidade.

$\mathrm{Na}$ luta contra o mito do monolinguismo e pela afirmação de políticas em prol das línguas minoritárias, Morello (2015) adverte que as línguas são um patrimônio histórico e cultural de todos os grupos que vivem em solo brasileiro. Dessa forma, a autora reitera a importância do projeto de cooficialização das línguas minoritárias no país. Esse projeto respeita o português, mas chama a atenção para a importância do uso das línguas minoritárias no cotidiano das comunidades colonizadas por imigrantes.

Hoje, no Espírito Santo, a língua pomerana está cooficializada em alguns municípios, fazendo com que ela seja ensinada nas escolas do Ensino Fundamental I, como vimos. Por meio do PROEPO, a cultura e a língua dos imigrantes pomeranos foram levadas para dentro do ambiente escolar e, dessa forma, a escola passou a ser espaço de inclusão da diversidade e de exclusão do preconceito.

Projetos como esse ainda não foram pensados para o vêneto em Alfredo Chaves, tendo em vista que o uso dessa língua dentro do município é baixo. Entretanto, faz-se importante investigar se existem comunidades no estado em que as línguas italianas de imigração - ou outras - sejam faladas, a fim de se elaborarem estratégias para a sua manutenção e/ou sua revitalização, haja vista a importância dessas línguas para a formação cultural e identitária do Espírito Santo. De acordo com nossos informantes e com os resultados de outros pesquisadores dos contatos linguísticos no estado, há um grande interesse das comunidades para que as línguas minoritárias não sejam esquecidas.

Dessa forma, acreditamos que ainda há tempo para que políticas de revitalização sejam elaboradas e implementadas, inclusive pela escola, a fim de que a diversidade linguística seja enfim reconhecida como um ganho, e não como obstáculo, como foi vista no passado. 


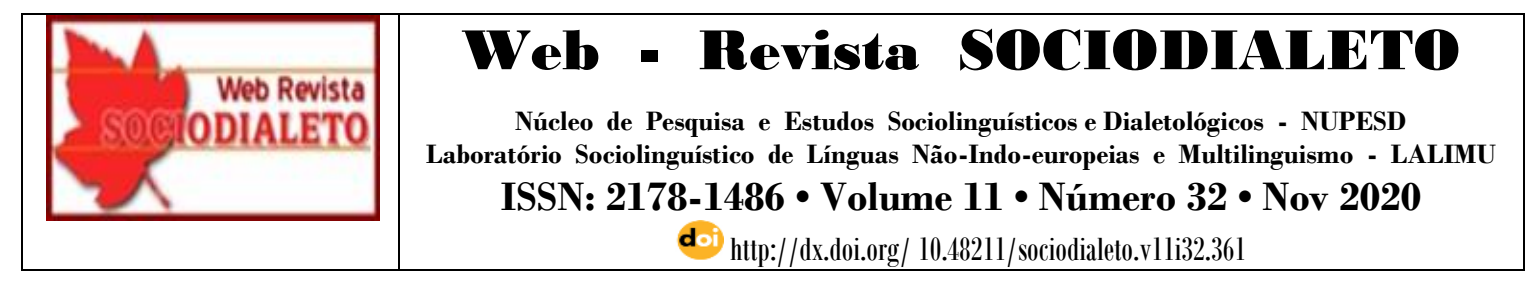

\section{Referências}

ABTAHIAN, M. R. Language shift. In: DARQUENNES, J.; SALMONS, J. C.; VANDENBUSSCHE, W. (Ed.) Language Contact; an international handbook. V. 1. Berlin/Boston: De Gruyter Mouton, 2019. p. 442-454.

APPEL, R.; MUYSKEN, P. Bilinguismo y contacto de lenguas. Barcelona: Ariel, 1996.

BAGNO, M. O que é uma língua? Imaginário, ciência \& hipóstase. In.: LAGARES, X.C.; BAGNO, M. (orgs.) Políticas da norma e conflitos linguísticos. São Paulo: Parábola, 2012, p. 355-387.

BAKER, C.; JONES, P. S. Encyclopedia of bilingualism and bilingual educacion. Clevedon. Avon, UK: Multilingual Matters, 1998.

BRASIL. Decreto $n^{\circ} 3.010$, de 20 de agosto de 1938. Regulamenta o decreto- -lei n. 406, de 4 de maio de 1938, que dispõe sobre a entrada de estrangeiros no território nacional. Diário Oficial da República Federativa do Brasil, Rio de Janeiro, 1938. Disponível em: <https://www2.camara.leg.br/legin/fed/decret/1930-1939/decreto-3010-20-agosto1938-348850-publicacaooriginal-1-pe.html>. Acesso em: 02 jun. 2018.

BRASIL. Decreto-Lei $\mathbf{n}^{0}$ 1545, de 25 de agosto de 1939. Dispõe sobre a adaptação ao meio nacional dos brasileiros descendentes de estrangeiros. Diário Oficial da República Federativa do Brasil. Rio de Janeiro, 28 jul. 1939. Disponível em: <https://www2.camara.leg.br/legin/fed/declei/1930-1939/decreto-lei-1545-25-agosto1939-411654-publicacaooriginal-1-pe.html>. Acesso em: 02 jun. 2018.

BRASIL. Decreto-Lei $n^{0}$ 406, de 04 de maio de 1938. Dispõe sobre a entrada de estrangeiros no território nacional. Diário Oficial da República Federativa do Brasil, Rio de Janeiro, 1938. Disponível em: <https://www2.camara.leg.br/legin/fed/declei/19301939/decreto-lei-406-4-maio-1938-348724-publicacaooriginal-1-pe.html>. Acesso em: 02 jun. 2018.

BREMENKAMP, E. S. Análise sociolinguística da manutenção da língua pomerana em Santa Maria de Jetibá, Espírito Santo. 293f. 2014. Dissertação (Mestrado). Programa de Pós-Graduação em Linguística, Universidade Federal do Espírito Santo, Vitória, 2014.

BRENZINGER, M. Language maintenance. In: DARQUENNES, J.; SALMONS, J. C.; VANDENBUSSCHE, W. (Ed.) Language Contact; an international handbook. V. 1. Berlin/Boston: De Gruyter Mouton, 2019. p. 454-467.

CAMPOS, A. P. Escravidão, reprodução endógena e crioulização: o caso do Espírito Santo no Oitocentos. Topoi (Online). Revista de História, v. 12, p. 84-96, 2011.

COMINOTTI, K. S. O contato linguístico entre o vêneto e o português em São Bento de Urânia, Alfredo Chaves, ES: uma análise sócio-histórica. 153f. 2015. Dissertação 


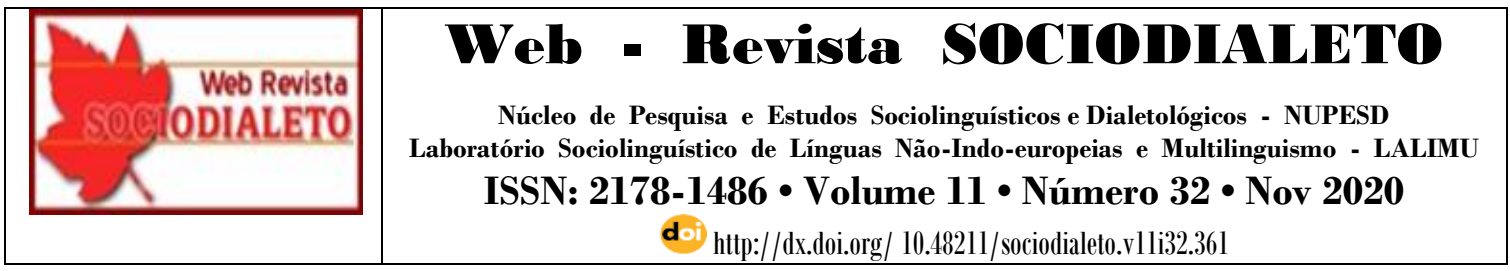

(Mestrado). Programa de Pós-Graduação em Linguística, Universidade Federal do Espírito Santo, Vitória, 2015.

CONDE, B. S. Senhores de fé e de escravos: a escravidão nas fazendas jesuíticas do Espírito Santo. In: Anais do $\mathbf{4}^{\mathbf{0}}$ Encontro Escravidão e Liberdade no Brasil Meridional. Universidade Federal do Paraná: 01-10, 2009. Disponível em https://bit.ly/2JpAkcr. Acesso em: 03 mar. 2014.

COULMAS, F. Sociolinguistics; the study of speakers' choices. Cambridge: Cambridge Press, 2005.

CRUZ, N. R. O ensino e a aprendizagem de língua em escolas de imigração e as políticas de nacionalização do ensino: o caso da escola particular Adventista de Gaspar Alto. 282f. 2015. Dissertação (Mestrado). Programa de Pós-Graduação em Linguística, Universidade de Santa Catarina (UFSC). Santa Catarina, 2015.

DADALTO, M. C.; BENEDUZI, L. F. Nós, o outro e os outros: a constituição multiétnica capixaba no caldeirão cultural do Espírito Santo, Brasil. Diaspore. Quaderni di ricerca, v. 12, p. 93-112, 2020.

FASOLD, R. La sociolingüística de la sociedad: Introducción a la sociolingüística. Tradução de Margarita España Villasante e Joaquín Mejía Alberdi. Madrid: Visor libros, 1996.

GARCÍA, O. Multilingual language awareness and teacher education. In: CENOZ, J.; HORNBERGER, N. H. (eds.). Encyclopedia of language and education. 2. ed. Volume 6: Knowledge about language. New York: Springer Science, 2008.

HARTUWiG, A.V.G. Professores(as) Pomeranos(as): um estudo de caso sobre o Programa de Educação Escolar Pomerana - Proepo - desenvolvido em Santa Maria de Jetibá/ES. 197 fl. 2011. Dissertação (Mestrado) - Programa de Pós-graduação em Educação, Universidade Federal do Espírito Santo, Vitória, 2011.

INSTITUTO BRASILEIRO DE GEOGRAFIA E ESTATÍSTICA (IBGE). Panorama. 2019. Disponível em: <https://cidades.ibge.gov.br/brasil/es/alfredo-chaves/panorama>. Acesso em: 19 set. 2019.

INVENTÁRIO NACIONAL DA DIVERSIDADE LINGUÍSTICA (INDL). Disponível em: http://portal.iphan.gov.br/indl. Acesso em: 09 out. 2020.

KLIPPEL-MACHADO, R. Práticas de escritas na escola em contexto de diversidade linguística: o contato entre as línguas portuguesa e hunsrückisch em Marechal Floriano, ES. 163f. 2018. Dissertação (Mestrado em Mestrado Profissional em Letras) - Instituto Federal do Espírito Santo, Vitória, 2018.

KÜSTER, I. M. Análise das interferências produzidas nas falas de bilíngues em pomerano e português em Laranja da Terra, ES. 155f. 2018. Dissertação (Mestrado em Letras) - Programa de Pós-Graduação em Letras. Pontifícia Universidade Católica de Minas Gerais, Belo Horizonte, 2018. 


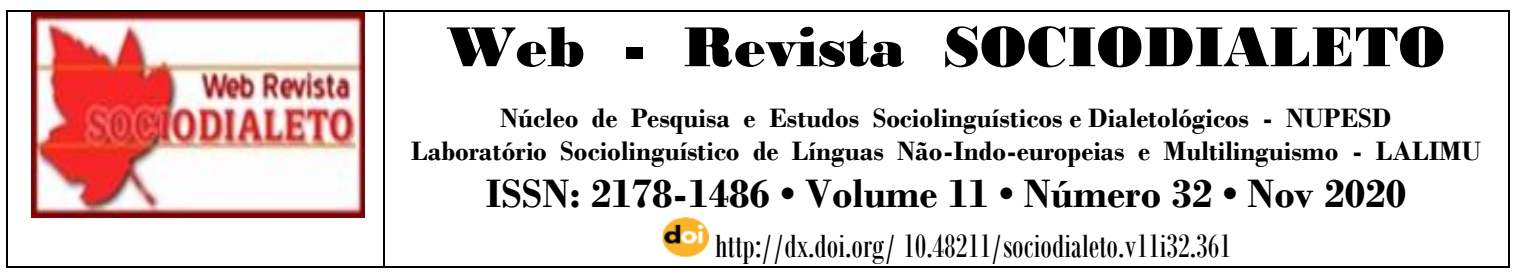

KUSTER, S. B. Cultura e língua pomeranas: um estudo de caso em uma escola do ensino fundamental no município de Santa Maria de Jetibá - Espírito Santo - Brasil. 255f. 2015. Dissertação (Mestrado). Programa de Pós-graduação em Educação. Universidade Federal do Espírito Santo, Vitória, 2015.

MATRAS, Y. Contact languages. Cambrigde: Cambridge University Press, 2009.

MONTRUL, S. El bilingüismo en el mundo hispanohablante. West Sussex, UK: Wiley-Blackwell, 2013.

MOREIRA, T. H.; PERRONE, A. História e geografia do Espírito Santo. Vitória: Ed. do Autor, 2007.

MORELLO, R. (Org.). Leis e línguas no Brasil: o processo de cooficialização e suas potencialidades. Florianópolis: IPOL, 2015.

OLIVEIRA, G. M. Os censos linguísticos e as políticas para as línguas no Brasil Meridional. In: MORELLO, R.; MARTINS, M. F. (Orgs.) Observatório da educação na fronteira: política linguística em contextos plurilíngues: desafios e perspectivas para a escola. Florianópolis: IPOL: Editora Garapuvu, 2016. p. 229-239.

ORLANDI, E. P. O discurso sobre a língua no período Vargas (Estado Novo 1937/1945). Línguas e Instrumentos Linguísticos, Campinas, SP: Pontes, n. 15, 2005. p. 27-33.

PAGANI, C. A imigração italiana no Rio de Janeiro e em Petrópolis e a educação para os filhos dos imigrantes $\mathbf{( 1 8 7 5}$ - 1920). 211f. 2012. Dissertação (Mestrado em Educação) - Faculdade de educação. Universidade Católica de Petrópolis. Petrópolis, Rio de Janeiro, 2012.

PERES, E. P. Aspectos sócio-históricos do contato entre o dialeto vêneto e o português no Espírito Santo. (Con)Textos linguísticos, Vitória, v. 8, n.1, p. 53-71, 2014.

PERES, E. P.; COMINOTTI, K. S. S.; DADALTO, M. C. O contato linguístico entre o vêneto e o português em São Bento de Urânia, Alfredo Chaves, ES: uma análise sóciohistórica. (Con)textos Linguísticos, Vitória, v. 9, p. 106-125, 2015.

PERTELE, B. D. Análise sociolinguística da realização do ditongo nasal tônico <ão> em São Bento de Urânia, Alfredo Chaves/ES: o papel da variável sexo / gênero. 146f. 2017. Dissertação de Mestrado. Programa de Pós-Graduação em Linguística, Universidade Federal do Espírito Santo, Vitória, 2017.

PICOLI-MENEGHEL, S. A. O ditongo nasal tônico -ão falado por ítalo-descendentes de Santa Maria do Engano, ES: uma análise sociolinguística. 132f. 2015. Dissertação (Mestrado em Estudos Linguísticos). Programa de Pós-Graduação em Linguística, Universidade Federal do Espírito Santo, Vitória, 2015.

PREFEITURA MUNICIPAL DE ALFREDO CHAVES. Prefeitura Municipal de Alfredo Chaves. Disponível em: <http://www.alfredochaves.es.gov.br>. Acesso em: 20 mai. 2018. 


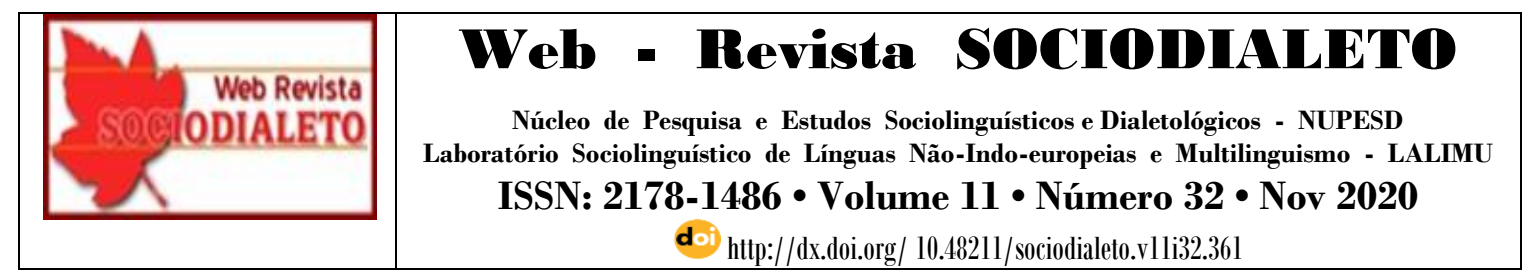

UNESCO. Language vitality and endangerment (Unesco Ad Hoc Group on Endangered Languages). Paris: Unesco, 2003. Disponível em: <http://www.unesco.org/culture/ich/doc/src/00120-EN.pdf>. Acesso em: 07 mai. 2011. WEINREICH, U. Languages in Contact: findings and problems. With a preface by André Martinet. 7th. ed. Paris: Mouton \& Co, 1970 [1953].

WINFORD, D. An introduction to contact linguistics. Malden, MA: Wiley, 2003.

Recebido Para Publicação em 01 de outubro de 2020.

Aprovado Para Publicação em 04 de novembro de 2020. 